Acta Theriologica $37(1-2): 15$ - 25, 1992.

PL ISSN 0001-7051

\title{
Genetic diversity in the Polish brown hare Lepus europaeus Pallas, 1778: implications for conservation and management
}

\author{
Günther B. HARTL, Janusz MARKOWSKI, Aleksander SWIĄTECKI, \\ Tomasz JANISZEWSKI and Rudolf WILLING
}

\begin{abstract}
Hartl G. B., Markowski J., Swiątecki A., Janiszewski T. and Willing R. 1992. Genetic diversity in the Polish brown hare Lepus europaeus Pallas 1778: implications for conservation and management. Acta theriol. 37: $15-25$.

A total of 193 brown hares, collected from 7 sampling sites in Poland during 1986 - 1990 were examined for genetic variability and differentiation at 39 presumptive isozyme loci by means of horizontal starch gel electrophoresis. Values of polymorphism (mean $P=0.180, \mathrm{SD} 0.039$ ) and average heterozygosity (mean $H=0.047$, SD 0.006 ) were similar to those detected in previous studies on the population genetics of the brown hare. Relative $\left(G_{\mathrm{ST}}=0.041\right)$ and absolute (mean D/Nei, 1978/ $=0.0012, \mathrm{SD}$ $0.0013)$ genetic differentiation among populations were very low, which fits well to the high number of migrant individuals per generation $(\mathrm{Nm}=12.7)$, estimated using the private allele method of Slatkin (1985). Average heterozygosity was examined for associations with geographical distribution, the year of culling, population density, age, sex, body weight and health status, whereby a better survival of heterozygous femals could be detected. According to our results, the present decline of the brown hare is not due to genetic depletion. However, once population sizes drop below a critical threshold, a pronounced inbreeding depression can be expected.
\end{abstract}

Forschungsinstitut für Wildtierkunde und Ökologie der Veterinärmedizinischen Universität Wien, Savoyenstraße 1, A-1160, Vienna, Austria (GBH, RW), Department of Ecology and Vertebrate Zoology, University of Łódz, Banacha str. 12/16, 90-237 Łódź, Poland (JM, TJ), Department of Microbiology, Teachers Training College, Żołnierska str. 14, 10-561 Olsztyn, Poland (AS)

Key words: Lepus europaeus, isozymes, haptoglobin, genetic diversity, gene flow, health status, Poland

\section{Introduction}

The brown hare (Lepus europaeus Pallas, 1778) is one of the most important game species inhabiting the cultivated landscape of Poland. According to Pielowski $(1976,1979)$ population density in the sixties ranged from several up to 50 animals per 100ha. The hunting bag was 700000 at the beginning of the seventies and decreased to 505000 at the end of that decade. A particular decrease was noticed 


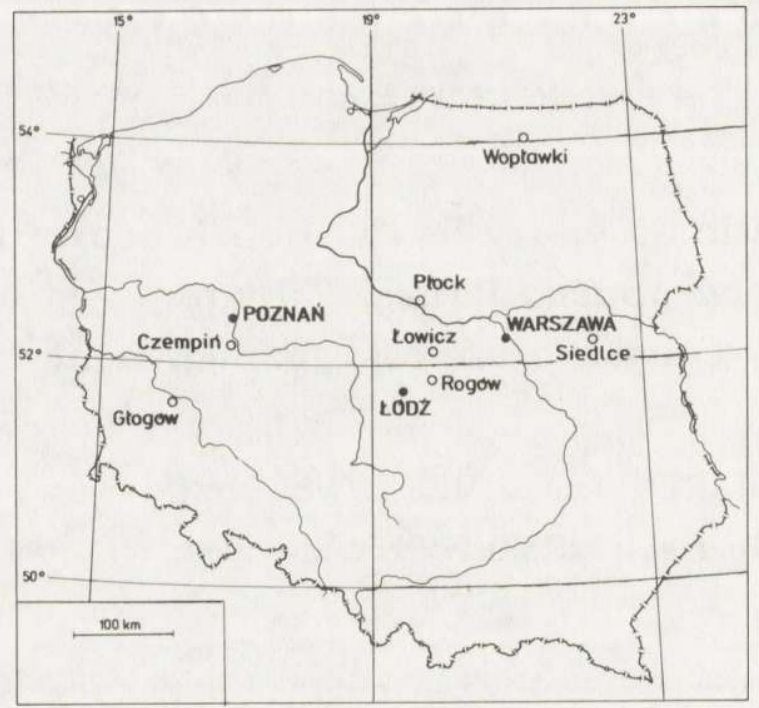

Fig. 1. Geographic location of hunting areas, marked by circles: Wopławki (WOP), Czempiń (CZE), Rogow (ROG), Siedlce (SIE), Głogów (GLO), Łowicz (LOW), Płock (PLO).

Table 1. Characteristics of hunting units. Ex - experimental hunting unit, LH - rented by local unit of Polish Hunting Association, LF - predominately large state farming, SM - predominately small farmng, ${ }^{*}=$ after Jezierski, Kryński, Pielowski and Wasilewski (pers. comm.).

\begin{tabular}{|c|c|c|c|c|c|c|}
\hline $\begin{array}{l}\text { Hunting unit/ } \\
\text { geographical location }\end{array}$ & $\begin{array}{c}\text { Total area, } \\
\text { ha }\end{array}$ & $\begin{array}{l}\text { Land } \\
\text { arable }\end{array}$ & $\begin{array}{c}\text { exploita } \\
\text { forest }\end{array}$ & $\begin{array}{l}\text { n, \% } \\
\text { others }\end{array}$ & Density* & $N / 100$ ha \\
\hline Wopławki/Mazurian Lakes & 4,903 & 85.0 & 2.0 & 13.0 & Ex, LF & 9 \\
\hline Czempiń/Leszno Lakes & 15,000 & 90.0 & 7.0 & 3.0 & Ex, LF & 20 \\
\hline Rogów/South-Mazovian & 13,000 & 74.0 & 23.0 & 3.0 & Ex, SM & $21-31$ \\
\hline Siedlce/South-Podlasie & 23,240 & 86.0 & 11.0 & 3.0 & LH, SM & $15-20$ \\
\hline Głogów/Dałków Upland & 2,048 & 85.0 & 13.5 & 1.5 & LH, SM & 20 \\
\hline Płock/Mazovian & 2,043 & 91.3 & 8.7 & 1.0 & LH, SM & 25 \\
\hline Łowicz/Mazovian & 7,099 & 93.0 & 1.8 & 5.2 & LH, SM & 40 \\
\hline
\end{tabular}

in the mid-eighties (Sikorski 1987). As stated by Pielowski (pers. comm.) the present Polish brown hare population is three to four times smaller than in the fifties. In order to find out the reasons for this rapid decline of the brown hare a special project was conducted in Poland from 1986 to 1990 (Jezierski 1988), whereby, among various other aspects, also genetic factors were considered. According to previous studies on brown hares from various parts of Europe a reduction of overall genetic variation (as indicated by electrophoretic markers) is not likely to affect the survival of this species (Bonhomme et al. 1986, Hartl et al. 
$1989,1990)$. It is, however, still a matter of debate, whether protein heterozygosity is actually a suitable indicator for overall genetic variation (see e. g. Frankel and Soule 1981, Schnell and Selander 1981, Palmer and Strobeck 1986, Lande and Barrowclough 1987). Furthermore, although protein heterozygosity was found to be associated with several aspects of ecological adaptation and fitness in various mammalian species (see e. g. Johns et al. 1977, Nevo 1983, 1988, Nevo et al. 1984, Wildt et al. 1987, Pemberton et al. 1988, Scribner and Smith 1990, Smith et al. 1990), its significance in the brown hare remains to be clarified.

A relation between heterozygosity at the haptoglobin locus and both the health status and the age structure of brown hare populations in Poland was reported by Markowski et al. (1990). In the present study, average heterozygosity as estimated by allozyme electrophoresis is examined in the brown hare from Poland in relation to geographical distribution, year of culling, population density, age, sex, body weight, and health status.

\section{Study area}

Seven hunting areas representing different physiographic regions of Poland were investigated (Fig.1). General characteristics of the study areas and population densities are given in Table 1.

\section{Material and methods}

A total of 193 specimens, obtained during the hunting seasons from 1986 to 1990 , were investigated. The hares were weighed, sexed and aged (using both the "Stroh-sign" - Stroh 1931, and the dry eye lens weight - Broekhuizen and Maaskamp 1979). Data on health status and haptoglobin polymorphism were taken from Markowski et al. (1990). Tissue (liver, kidney, heart, skeletal muscle) samples were frozen in liquid nitrogen immediately after death of the animals. Preparation of tissue extracts, electrophoretic and staining procedures, and the interpretation of band-patterns were performed as described and referenced in Hartl and Höger (1986) and Hartl et al. (1988). The following isozyme systems were screened (abbreviation and E.C. are given in parentheses):

$\alpha$-glycerophosphate dehydrogenase (GDC, E.C. 1.1.1.8), sorbitol dehydrogenase (SDH, E.C. 1.1.1.14), lactate dehydrogenase (LDH, E.C. 1.1.1.27), malate dehydrogenase (MOR, E.C. 1.1.1.37), isocitrate dehydrogenase (IDH, E.C. 1.1.1.42), 6-phosphogluconate dehydrogenase (PGD, E.C. 1.1.1.44), glucose dehydrogenase (GDH, E.C. 1.1.1.47), glucose-6-phosphate dehydrogenase (GPD, E.C. 1.1.1.49), xanthine dehydrogenase (XDH, E.C. 1.2.3.2), glutamate dehydrogenase (GLUD, E.C. 1.4.1.3), catalase (E.C. 1.11.1.6), superoxide dismutase (SOD (E.C. 1.15.1.1), glutamate oxaloacetate transaminase (GOT, E.C. 2.6.1.1), hexokinase (HK, E.C. 2.7.1.1), creatine kinase (CK, E.C. 2.7.3.2), adenylate kinase (AK, E.C. 2.7.4.3), phosphoglucomutase (PGM, E.C. 2.7.5.1), esterases (ES, E.C. 3.1.1.1), acid phosphatases (ACP, E.C. 3.1.3.2), peptidases (PEP, 3.4.11), aminoacylase-1 (ACY-1, E.C. 3.5.1.14), adenosine deaminase (ADA, E.C. 3.5.4.4), fumarate hydratase (FH, E.C. 4.2.1.2), mannosephosphate isomerase (MPI, E.C. 5.3.1.8), and glucosephosphate isomerase (GPI, E.C. 5.3.1.9).

Values of polymorphism and heterozygosity were calculated according to Ayala (1982). The number of migrating individuals per generation $(\mathrm{Nm})$ was estimated using Slatkin's (1985) private allele method. Gene diversity between populations in relation to gene diversity within populations was calculated using Nei's (1975) $G$-statistics. Absolute genetic distances between populations was calculated using various genetic distance measures (Nei 1972, Nei 1978, Rogers 1986). Dendrograms 
Table 2. Allelic frequencies at the polymorphic loci in Polish brown hare populations (99\% criterion). The data are pooled from all sampling seasons. $\mathrm{X}=$ not studied.

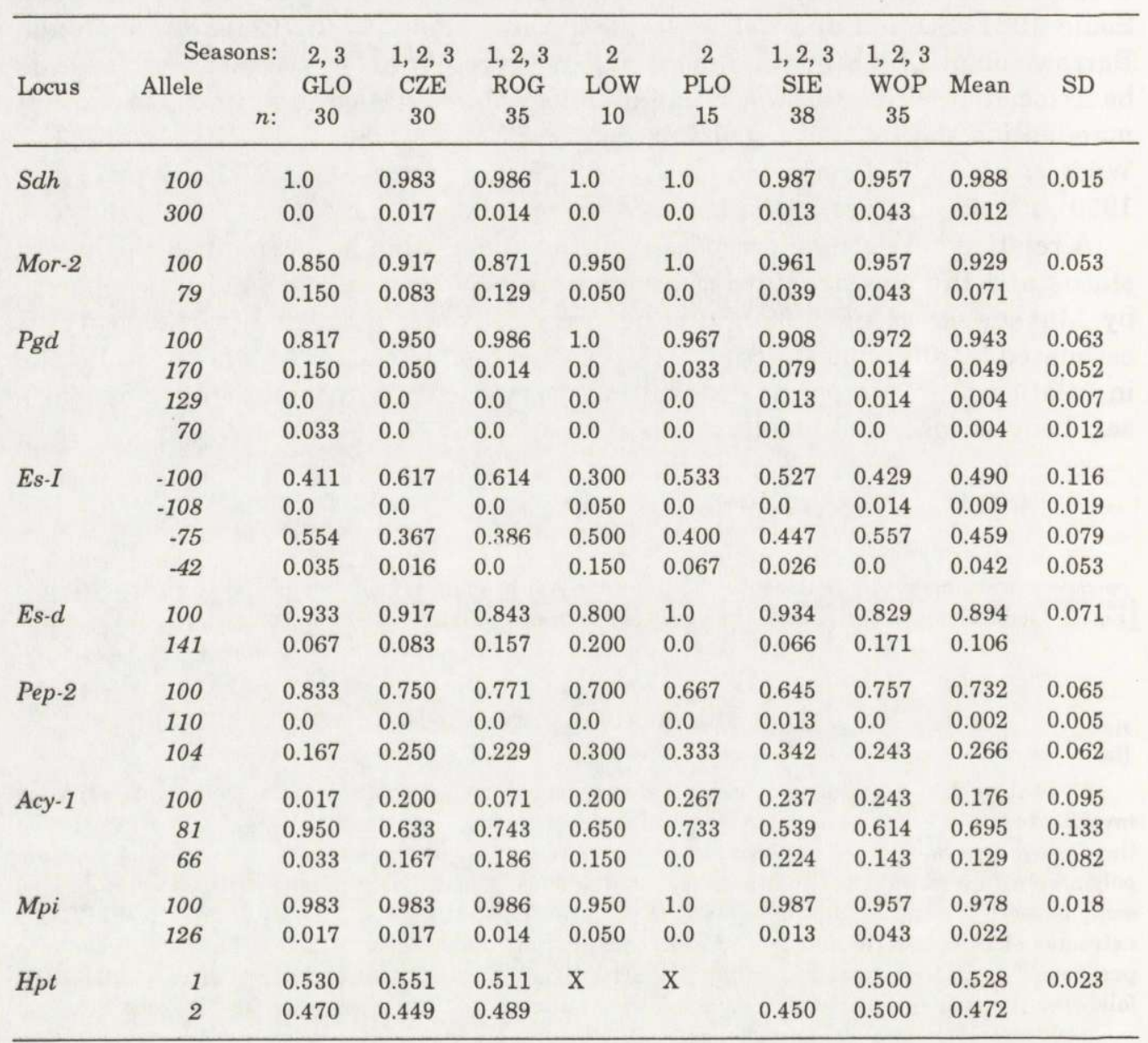

were constructed according to different algorithms using the PHYLIP-programme package of Felsenstein (see Felsenstein 1985). The influence of sample size and the composition of polymorphic loci on the stability of clusters was tested by means of the bootstrap and the jackknife method as described in detail by Hartl et al. (1990).

\section{Results}

Twenty five isozyme systems representing a total of 39 presumptive structural loci (identical with those examined by Hartl et al. 1990) were screened. Genetic polymorphism was detected at the following 8 loci: Sdh, Mor-2, Pgd, Es-I, Es-d, Pep-2, Acy-1, and Mpi. All of these loci were previously found to be polymorphic 
Table 3. Genetic variability in Polish brown hare populations. $h\left(h_{0}\right)=$ excepted (observed) heterozygosity, $H\left(H_{0}\right)=$ excepted (observed) average heterozygosity, $P=$ proportion of polymorphic loci (calculated oyer 39 loci, $H p t$ excluded), $\mathrm{X}=$ not studied.

\begin{tabular}{lclllllllll}
\hline Locus & & GLO & CZE & ROG & LOW & PLO & SIE & WOP & Mean & SD \\
\hline Sdh & $h$ & 0.0 & 0.033 & 0.028 & 0.0 & 0.0 & 0.026 & 0.082 & 0.024 & 0.029 \\
& $h_{0}$ & 0.0 & 0.033 & 0.029 & 0.0 & 0.0 & 0.026 & 0.086 & 0.025 & 0.031 \\
Mor-2 & $h$ & 0.255 & 0.152 & 0.225 & 0.095 & 0.0 & 0.075 & 0.082 & 0.126 & 0.090 \\
& $h_{0}$ & 0.233 & 0.167 & 0.200 & 0.100 & 0.0 & 0.079 & 0.086 & 0.124 & 0.081 \\
Pgd & $h$ & 0.309 & 0.095 & 0.028 & 0.0 & 0.064 & 0.169 & 0.055 & 0.089 & 0.102 \\
& $h_{0}$ & 0.333 & 0.100 & 0.029 & 0.0 & 0.067 & 0.184 & 0.057 & 0.110 & 0.115 \\
Es-I & $h$ & 0.523 & 0.484 & 0.474 & 0.635 & 0.551 & 0.522 & 0.506 & 0.528 & 0.054 \\
& $h_{0}$ & 0.429 & 0.367 & 0.486 & 0.500 & 0.333 & 0.579 & 0.429 & 0.446 & 0.084 \\
Es-d & $h$ & 0.125 & 0.152 & 0.265 & 0.320 & 0.0 & 0.123 & 0.284 & 0.181 & 0.113 \\
& $h_{0}$ & 0.133 & 0.167 & 0.257 & 0.400 & 0.0 & 0.132 & 0.286 & 0.196 & 0.130 \\
Pep-2 & $h$ & 0.278 & 0.375 & 0.353 & 0.420 & 0.444 & 0.467 & 0.368 & 0.386 & 0.064 \\
& $h_{0}$ & 0.267 & 0.367 & 0.343 & 0.400 & 0.533 & 0.500 & 0.429 & 0.406 & 0.092 \\
Acy-1 & $h$ & 0.096 & 0.531 & 0.408 & 0.515 & 0.391 & 0.603 & 0.542 & 0.441 & 0.170 \\
& $h_{0}$ & 0.100 & 0.567 & 0.429 & 0.700 & 0.400 & 0.605 & 0.600 & 0.486 & 0.200 \\
Mpi & $h$ & 0.033 & 0.033 & 0.028 & 0.095 & 0.0 & 0.026 & 0.082 & 0.042 & 0.034 \\
& $h_{0}$ & 0.033 & 0.033 & 0.029 & 0.100 & 0.0 & 0.026 & 0.086 & 0.044 & 0.036 \\
Hpt & $h$ & 0.498 & 0.495 & 0.500 & $\mathrm{X}$ & $\mathrm{X}$ & 0.495 & 0.500 & 0.498 & 0.003 \\
& $h_{0}$ & 0.733 & 0.632 & 0.640 & & & 0.757 & 0.591 & 0.671 & 0.071 \\
\hline & $H$ & 0.042 & 0.048 & 0.046 & 0.053 & 0.037 & 0.052 & 0.051 & 0.047 & 0.006 \\
& $H_{0}$ & 0.039 & 0.046 & 0.046 & 0.056 & 0.034 & 0.055 & 0.053 & 0.047 & 0.008 \\
& $P$ & 0.180 & 0.205 & 0.205 & 0.154 & 0.103 & 0.205 & 0.205 & 0.180 & 0.039 \\
\hline
\end{tabular}

in the brown hare (Hartl et al. 1989, 1990) and for several of them the Mendelian inheritance of the respective allozymes was proved by family studies (Hartl 1987, 1991). Except for Pep- $2^{110}$, also all of the alleles were described previously in at least in one of four countries (Poland, Hungary, Austria, Czechoslovakia) examined and the nomenclature is consistent with that used by Hartl et al. (1990). The allele frequencies are listed in Table 2 . The proportion of polymorphic loci $(P)$, single locus heterozygosities $(h)$ and average heterozygosity $(H)$ for each of the populations studied is given in Table 3 . The number of migrating individuals per generation $(\mathrm{Nm})$ is $12.7(\bar{p}(1)=0.023)$, relative genetic differentiation among populations is $4 \%\left(G_{\mathrm{ST}}=0.041, H_{\mathrm{S}}=0.047, H_{\mathrm{T}}=0.049, D_{\mathrm{ST}}=0.002\right)$. Pairwise genetic distances between populations, corrected for sample sizes (Nei 1978), are given in Table 4 (mean $D=0.0012$, SD 0.0013). 
Table 4. Genetic identities - above the diagonal and genetic distances - below the diagonal - between Polish brown hare populations, calculated according to Nei (1978) over 39 loci (Hpt excluded).

\begin{tabular}{lccccccc}
\hline & GLO & CZE & ROG & LOW & PLO & SIE & WOP \\
\hline GLO & - & 0.9970 & 0.9979 & 0.9976 & 0.9971 & 0.9956 & 0.9970 \\
CZE & 0.0030 & - & 1.0001 & 0.9995 & 0.9998 & 1.0000 & 0.9995 \\
ROG & 0.0021 & -0.0001 & - & 0.9992 & 0.9985 & 0.9986 & 0.9990 \\
LOW & 0.0024 & 0.0005 & 0.0008 & - & 0.9995 & 0.9998 & 1.0011 \\
PLO & 0.0029 & 0.0002 & 0.0015 & 0.0005 & - & 0.9996 & 0.9989 \\
SIE & 0.0044 & -0.0000 & 0.0014 & 0.0002 & 0.0004 & - & 0.9995 \\
WOP & 0.0030 & 0.0030 & 0.0005 & 0.0010 & -0.0011 & 0.0011 & - \\
\hline
\end{tabular}

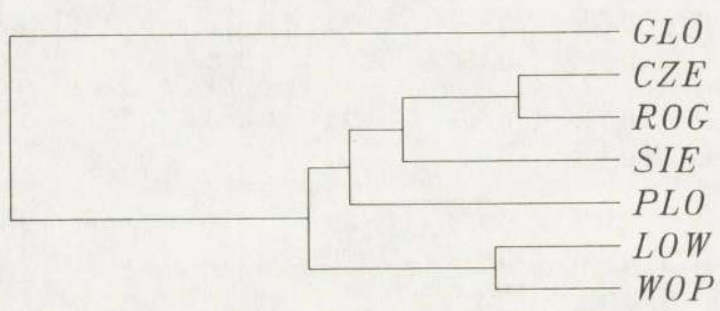

Fig. 2. Dendrogram showing genetic relationships among Polish brown hare populations (Nei's 1972 $\mathrm{D}$ over 39 loci/UPGMA, branching point of $\mathrm{GLO}=0.0040$ ).

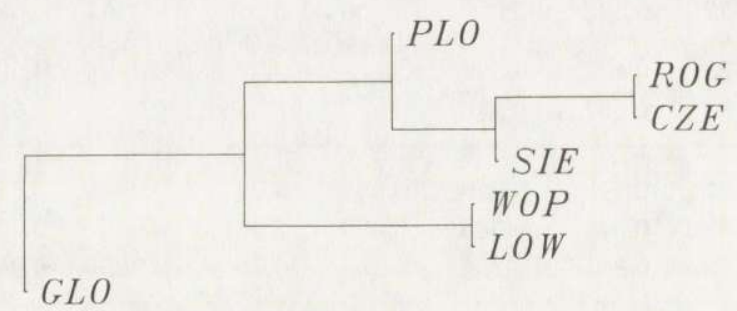

Fig. 3. Majority rule jackknife consensus tree showing stability of the clusters as to the composition of polymorphic loci chosen (based on Nei's 1972 D over 39 loci, the WOP and LOW cluster was found in 97 out of 100 trees).

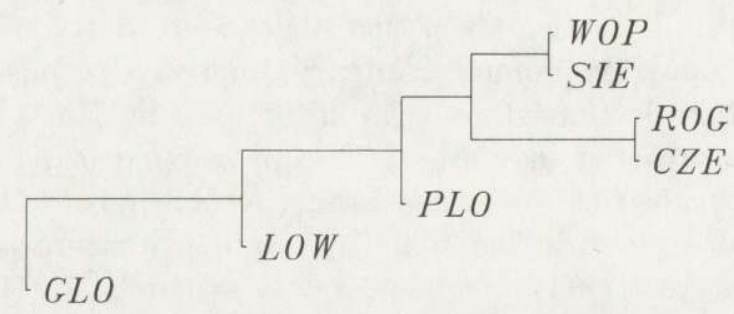

Fig. 4. Majority rule bootstrap consensus tree showing stability of the clusters as to variation in sample sizes (based on Nei's 1972 D over 39 loci, the position of GLO as shown in the Figure was stable in 53 out of 100 trees). 


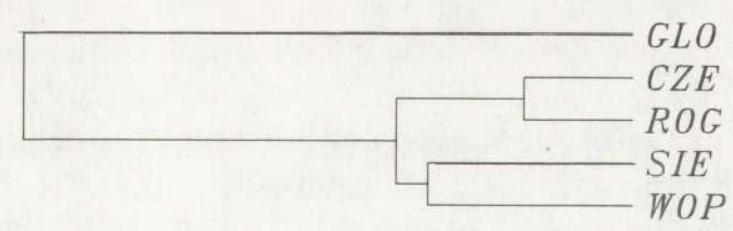

Fig. 5. Dendrogram showing genetic relationships among Polish brown hare populations (Nei's 1972 D over 40 loci/UPGMA). LOW and PLO are excluded because of small sample sizes. The topology remains the same when Nei's 1978 genetic distances are used or when $H p t$ is excluded.

Genetic similarity among the populations studied is shown in a dendrogram constructed by means of Nei's (1972) D and the UPGMA (Fig. 2). A majority rule jackknife consensus tree and a majority rule bootstrap consensus tree, giving an impression of the stability of clusters, are presented in Figs. 3 and 4, respectively. A Nei's (1972) D/UPGMA-tree, where two populations with small sample sizes are excluded, is shown in Fig. 5.

Whereas geographical differences in average heterozygosity were detected (especially the sample PLO showed remarkably low levels of $H$ and $P$ ), there were no significant differences among populations or individuals as to population density, the year of culling, body weight and health status. However, a test of homogenity revealed a trend for differences in average heterozygosity between sexes $\left(H_{0}\right.$ higher in females) as well as between juveniles and adults $\left(H_{0}\right.$ higher in the latter). Furthermore, $H$ and $H_{0}$ increased with the frequency of females in the populations surveyed $(r=0.772, n=6, p<0.05$, Sperman rank correlation coefficient).

\section{Discussion}

With a mean $P$ of $18 \%$ (SD $3.9 \%$ ) and a mean $H$ of $4.7 \%$ (SD $0.6 \%$ ) values of polymorphism and average heterozygosity detected in the present analysis are very similar to those reported previously for Polish, Austrian, Hungarian and Czechoslovakian populations (Hartl et al. 1989 - mean $P=16 \%$, mean $H=4.7 \%$, 54 loci, Hartl et al. 1990 - mean $P=16 \%$, mean $H=4.8 \%$, 39 loci). The sample from PLO, however, exhibits considerably lower values of $P$ and $H$, which is not necessarily the result of the comparatively low sample size of 15 (similar to many sample sizes in Hartl et al. 1989, 1990). It is also hardly to be explained only by the comparatively strong isolation of this population by industrial areas and a town in the north, a large forest in the east, a strongly frequented road in the south, a river in the south-west and a town in the north-east (see below). However, in conjunction with a particularly severe reduction of population size during the population crash in the mid-eighties (see Introduction), isolation could have produced a founder effect, resulting in the lack of many rare alleles (comp. Nei et al. 1975, Hartl 1989). 
In accordance with previous investigations (Hartl et al. 1989, 1990), relative gene diversity among populations is low $\left(G_{\mathrm{ST}}=4 \%\right)$, which is confirmed by the very high number of migrating individuals per generation $(\mathrm{Nm}=13$, comp. review in Table 7 of Slatkin 1985). Absolute genetic distances, which were already found to be extremely low over large geographic distances by Hartl et al. (1990), proved to be still lower only within Poland in the present investigation.

The dendrogram showing genetic similarity among populations (Fig. 2) is not in good agreement with the geographic location of the sampling sites. A check for the influence of the composition of polymorphic loci (Fig. 3) and for the influence of sample size (Fig. 4) on the topology of the tree revealed the latter to be quite high in our case. Therefore we constructed another dendrogram (Fig. 5) excluding the samples from LOW $(n=10)$ and PLO $(n=15)$, which proved to be in better agreement with the distribution of sampling sites. Although $\mathrm{Hpt}$ genotypes were found to be associated with the health status of the brown hare and, thus, allele frequencies may be affected by selection (Markowski et al. 1990), the presence or absence of $\mathrm{Hpt}$ data did not affect the topology of the tree. However, when other distance and cluster algorithms were used, except for the very separated position of GLO, the pattern turned out to be still ambiguous, which is to be explained by the very low and similar genetic distances. Again, since samples were collected from both sides of the Odra river, and according to previous results (Hartl et al. $1989,1990)$, geographic isolation is most probably not the reason for the exposed position of GLO in the dendrograms. Therefore, we suppose, that it is due to introgression from populations in eastern Germany, as yet not genetically examined.

Regarding the significance of protein heterozygosity as an indicator for fitness, demography and overall genetic variation in the brown hare, the following conclusions emerge from this and previous investigations:

Our data suggest a better survival of heterozygous females, which is an important fitness component and may have considerable influence on the genetic structure of populations. This result may contribute to an explanation for the high proportion of adult femals recognized in the hunting bags in the course of the brown hare project (comp. Markowski, in preparation). We failed to detect significant correlations of heterozygosity with body weight and health status, but this may be due to our comparatively small sample sizes, which also prohibited the conduction of multivariate analyses. Average heterozygosity was also not associated with developmental homeostasis (comp. Soulé 1979, Frankel and Soulé 1981, Palmer and Strobeck 1986), at least when the overall degree of fluctuating asymmetry in non-metric skull traits was considered as a possible indicator for the latter (Petznek et al. 1990, Markowski and Hartl 1991).

We did not detect any relationship between heterozygosity and the year of culling or population density. Whereas the former result may also be due to small sample sizes of both individuals and populations, we are quite confident in the latter, at least as far as the simple expectation of an increase of heterozygosity 
with population size is concerned (comp. Nei 1975). The lack of a relationship between heterozygosity and population density is in accordance with population genetic data from Austrian hares, where biochemical genetic diversity was sometimes even higher in areas with unfavourable habitat conditions and low population densities than in typical brown hare habitats (Hartl et al., in preparation).

Generally, the high extent of gene diversity within populations and the low genetic differentiation between populations observed in all our population genetic studies indicate, that the decline of the brown hare in Central Europe is not the result of genetic depletion. However, these results also suggest, that the hare as an outbreeder with high genetic variation may be particularly susceptible to inbreeding depression, if, due to a further rapid reduction, population sizes drop below a critical threshold (various symptoms of inbreeding depression in a small captive brown hare breed were described by Hartl et al. 1991).

Acknowledgements: The excellent technical assistance of Anita Haiden is gratefully acknowledged.

\section{References}

Ayala F. J. 1982. Population and evolutionary genetics: A primer. Benjamin Cummings, Menlo Park, CA: $1-268$.

Bonhomme F., Fernandez J., Palacios F., Catalan J. and Machordon A. 1986. Caractérisation biochimique du complexe d'espces du genre Lepus en Espagne. Mammalia 50: 495 - 506.

Broekhuizen S. and Maaskamp F. 1979. Age determination in the European hare (Lepus europaeus Pallas) in The Netherlands. Z. Säugetierk. 44: 162 - 175.

Felsenstein J. 1985. Confidence limits on phylogenies: an approach using the bootstrap. Evolution 39: $783-791$.

Frankel O. H. and Soulé M. E. 1981. Conservation and evolution. Cambridge University Press, Cambridge: $1-327$.

Hartl G. B. 1987. Biochemical differentiation between the Wild rabbit (Oryctolagus cuniculus L.), the Domestic rabbit and the Brown hare (Lepus europaeus Pallas). Z. zool. Syst. Evolut.-forsch. 25: $309-316$.

Hartl G. B. 1989. Die genetische Variabilität von Wildsäugern und die Folgen der Isolation. [In: Die Illusion der Arche Noah - Gefahren für die Arterhaltung durch Gefangenschaftszucht. E. Schneider, H. Oelke and H. Gross, eds]. Echo-Verlag, Göttingen: 127 - 138.

Hartl G. B. 1991. Genetic polymorphism of sorbitol dehydrogenase in the brown hare and the distribution of the variation in Central Europe. Biochemical Genetics 29: 49 - 54 .

Hartl G. B. and Höger H. 1986. Biochemical variation in purebred and crossbred strains of domestic rabbits (Oryctolagus cuniculus L.). Genetical Research, Camb. 48: 27 - 34.

Hartl G. B., Markowski J., Kovàcs G., Grillitsch M. and Willing R. 1990. Biochemical variation and differentiati on in the Brown hare (Lepus europaeus) of Central Europe. Z. Säugetierk. 55: $186-193$.

Hartl G. B., Suchentrunk F., Willing R. and Grillitsch M. 1989. Biochemisch-genetische Variabilität und Differenzierung beim Feldhasen (Lepus europaeus) in Niederösterreich. Wien. Tierärztl. Mschr. 76: $279-284$.

Hartl G. B., Vodnansky M., Suchentrunk F., Steineck Th., Willing R., Tataruch F. and Oberwalder U. 1991. Fortpflanzungsstörungen in einer Feldhasenzucht - Folge einer Inzuchtdepression? Verh. Ber. Erkrkg. Zootiere 33, Akademie-Verlag, Berlin: 17 - 26. 
Hartl G. B., Willing R., Grillitsch M. and Klansek E. 1988. Biochemical variation in Mustelidae: are carnivores genetically less variable than other mammals. Zool. Anzeiger 221: 81 - 90 .

Jezierski W. 1988. Lagomorph programme in Poland. Lagomorph Newslett. 8: 11 - 12.

Johns P. E. Baccus R., Manlove M. N., Pinder J. E. III. and Smith M. H. 1977. Reproductive patterns, productivity and genetic variability in adjacent white-tailed deer populations. Proc. Ann. Conf. Southeast Assoc. Fish. Wildl. Agencies 31: 167 - 172.

Lande R. and Barrowclough G. F. 1987. Effective population size, genetic variation, and their use in population management. [In: Viable Populations for Conservation. M. E. Soulé, ed.]. Cambridge University Press, Cambridge: 87 - 123.

Markowski J., Osmulski P., Duda W., Dyner E., Swiątecki A., Ułańska M. and Janiszewski T. 1990. Relation between haptoglobin polymorphism and the health status of brown hare populations in Poland. Acta theriol. 35: $215-224$

Markowski J. and Hartl G. B. 1991. Enzyme polymorphism and epigenetic asymmetry in the brown hare (Lepus europaeus Pal.) from Poland. Trans. 20th IUGB Congress, Gödöllö 1990. Hungary, August 1991: $835-840$.

Nei M. 1972. Genetic distance between populations. American Naturalist, 106: 283 - 292.

Nei M. 1975. Molecular population genetics and evolution. North-Holland, Amsterdam: $1-288$.

Nei M., Maruyama T. and Chakraborty R. 1975. The bottleneck effect and genetic variability in populations. Evolution 29: 1 - 10 .

Nei M. 1978. Estimation of average heterozygosity and genetic distance from a small number of individuals. Genetics 89: $583-590$.

Nevo E. 1983. Population genetics and ecology: the interface. [In: Evolution from molecules to men. D. S. Bendall, ed.]. Cambridge University Press, Cambridge: 287 - 321.

Nevo E. 1988. Genetic diversity in nature: patterns and theory. [In: Evolutionary biology. M. K. Hecht and B. Wallace, eds]. Plenum Publishing Corporation, 23: 217 - 246.

$\mathrm{Ne}^{\circ} \curvearrowleft$ E., Beiles A. and Ben-Shlomo R. 1984. The evolutionary significance of genetic diversity: ecological, demographic and life history correlates. [In: Evolutionary dynamics of genetic diversity. Lecture notes in biomathematics. G. S. Mani, ed.]. Springer Verlag, Berlin: 13 - 213.

Palmer A. R. and Strobeck C. 1986. Fluctuating asymmetry: measurement, analysis, patterns. Ann. Rev. Ecol. Syst. 17: $391-421$.

Pemberton J. M., Albon S. D., Guinness F. E., Clutton-Brock T. H. and Berry R. J. 1988. Genetic variation and juvenile survival in red deer. Evolution 42: 921 - 934.

Petznek R., Suchentrunk F., Hartl G. B. and Willing R. 1990. Enzyme heterozygosity and variability of non-metric skull traits in the brown hare (Lepus europaeus). Proc. 2nd Symposium on the Genetics of Wild Animals, Gießen 1990: in press.

Pielowski Z. 1976. On the present state and perspectives of the European hare breeding in Poland. [In: Ecology and management of European hare populations. Z. Pucek and Z. Pielowski, eds]. PWRiL, Warszawa: $25-27$.

Pielowski Z. 1979. Zając. Monografia przyrodniczo-łowiecka. PWRiL, Warszawa: 1 - 154.

Rogers J. S. 1986. Deriving phylogenetic trees from allele frequencies: a comparison of nine genetic distances. Syst. Zool. 35: $297-310$.

Schnell G. D. and Selander R. K. 1981. Environmental and morphological correlates of genetic variation in mammals. [In: Mammalian population genetics. M. H. Smith and J. Joule, eds]. University of Georgia Press, Athens: 60 - 99.

Scribner K. T. and Smith M. H. 1990. Genetic variability and antler development. [In: Horns, Pronghorns, and Antlers. G. A. Bubenik and A. B. Bubenik, eds]. Springer Verlag, Berlin: $460-$ 473

Sikorski J. 1987. Kierunki rozwoju gospodarki łowieckiej. Łow. pol. 11: 4 - 7 .

Slatkin M. 1985. Rare alleles as indicators of gene flow. Evolution 39: $53-65$,

Smith M. H., Willis K. B. and Johns P. E. 1990. Spatial-genetic variation in a white-tailed deer herd. Trans. 19th IUGB Congress, Trondheim 1989: 80 - 84 . 
Soulé M. E. 1979. Heterozygosity and developmental stability: another look. Evolution 33: $369-401$. Stroh G. 1931. Zwei sichere Altersmerkmale beim Hasen. Berliner Tierärztl. Wschr. 47: 180 - 181.

Wildt D. E., Bush M., Goodrowe K. L., Packer C., Pusey A. E., Brown J. L., Joslin P. and O'Brien S. J. 1987. Reproductive and genetic consequences of founding isolated lion populations. Nature 329: $328-331$.

Received 17 February 1992, accepted 21 March 1992. 